\title{
Characterization of a Lipid Hydroperoxide-Derived RNA-Adduct in Rat Intestinal Epithelial Cells
}

\author{
Peijuan Zhu, Seon Hwa Lee, Suzanne Wehrli ${ }^{1}$, and lan A. Blair ${ }^{*}$ \\ Center for Cancer Pharmacology, University of Pennsylvania School of Medicine, 854 BRBII/III, 421 Curie \\ Boulevard, Philadelphia, PA 19104-6160 \\ 1 Joseph Stokes, Jr., Research Institute, Children's Hospital of Philadelphia, Philadelphia, Pennsylvania \\ 19104
}

\section{Abstract}

Five major products (adducts $A_{1 a}, A_{1 b}, A_{2}, A_{3}$ and $B$ ) from the reaction of guanosine (Guo) with 4oxo-2(E)-nonenal (ONE) were detected by liquid chromatography-mass spectrometry (LC-MS). Tandem MS (MS/MS) analysis of these compounds suggested that modifications to the nucleoside had been introduced. Adducts $\mathrm{A}_{1 \mathrm{a}}, \mathrm{A}_{1 \mathrm{~b}}, \mathrm{~A}_{2}, \mathrm{~A}_{3}$ were heptanone-ethano-2'-Guo adducts that all decomposed to adduct $\mathrm{B}$. Adducts $\mathrm{A}_{1 \mathrm{a}}$ and $\mathrm{A}_{1 \mathrm{~b}}$ were isomeric hemi-ketal forms. Adducts $\mathrm{A}_{2}$ and $\mathrm{A}_{3}$ were diastereomers of the open chain ketone form. The structure of adduct $\mathrm{B}$ was shown by LCMS/MS and NMR spectroscopy to be the heptanone-etheno-Guo (HeGuo) adduct, 3-(Derythropentafuranosyl)imidazo-7-(heptane-2"-one)-9-hydroxyl[ 1,2- $\alpha]$ purine. The overall reaction of Guo with ONE was very similar to its reaction with 2'-deoxyguanosine. Reaction of ONE with yeast transfer RNA also resulted in the formation of HeGuo. Finally, $\mathrm{H} \varepsilon \mathrm{Guo}$ was detected and quantified in the RNA from rat intestinal epithelial cells that stably express cyclooxygenase-2. These data show that RNA is modified by the same bifunctional reactive electrophiles derived from lipid peroxidation that covalently modify DNA.

\section{Keywords}

lipid peroxidation; RNA-adducts; heptanone-etheno-adducts; 4-oxo-2(E)-nonenal; LC-MS; stable isotope dilution

\section{Introduction}

\begin{abstract}
Lipid peroxidation can occur when cells are subjected to oxidative stress $(1,2)$. Homolytic decomposition of lipid hydroperoxides leads to the formation of reactive bifunctional electrophiles, including 4-hydroperoxy-2(E)-nonenal (HPNE) (1,2), 4-oxo-2(E)-nonenal (ONE) (1,2) 4-hydroxy-2(E)-nonenal (HNE) (2,3) 4,5-epoxy-2(E)-decenal (EDE) (4). HPNE is the precursor to both ONE and HNE $(2,5,6)$. COX-2, which is upregulated in colon cancer (7-9) can also form lipid hydroperoxides from arachidonic acid (10). ONE forms both heptanone-ethano and heptanone-etheno-adducts with 2'-deoxyguanosine (dGuo) (11) 2'deoxyadenosine $(12,13) 2^{\prime}$-deoxycytidine (14) as well as heptanone-etheno-adducts with DNA in vitro $(6,11,12,15)$. The heptanone-ethano adducts formed with 2 '-deoxynucleosides readily decompose to heptanone-etheno adducts (11-14). Heptanone-etheno DNA-adducts have been detected in the DNA of rat intestinal epithelial cells that stably express COX-2 (RIES cells)
\end{abstract}


(10). They were also more abundant in intestinal DNA of Min mice (a model of colon cancer) when compared with controls (15). Furthermore, we recently showed that the heptanoneetheno-2'-deoxycytidine adduct was highly mutagenic in both bacteria and human cells. ${ }^{1}$ These results implicate that oxidative stress and lipid peroxidation can play an important role in carcinogenesis and other age-related diseases.

While the formation of DNA-adducts has been studied extensively, relatively fewer studies have been conducted with RNA. Since RNA has a similar structure to DNA, RNA was expected to show similar reactivity to lipid hydroperoxide-derived bifunctional electrophiles. Previous studies have shown that RNA can react with many carcinogens to form RNA-adducts. For example, Cardona et al. (16) reported that adducts can form between RNA and arylamines such as arylacethydroxamic acids, $N$-hydroxy- $N$-2-acetylaminofluorene, $N$-hydroxy- $N$-4acetylaminobiphenyl and their corresponding acetamides under radiation. Subsequently, King et al. showed that these adducts can be formed in isolated parenchymal rat liver cells (17). Studies with aminostilbene, N-nitroso-di- $n$-propylamine and 7-sulfooxymethyl-12-methylbenz $[a]$ anthracene have shown that RNA-adducts can be formed in vivo (18-20). Murphy et $a l$. have shown that RNA-adducts can arise from the reactive eicosanoid leukotriene $\mathrm{A}_{4}$ in calcium ionophore-treated human neutrophils $(21,22)$. Finally, Sotomayor et al. identified RNA-adducts that were derived from the environmental carcinogen aflatoxin $B_{1}(23)$. These studies suggest that RNA is a target of electrophiles in a similar manner to DNA, although further studies are required in order to address the biological significance of these observations.

Unlike DNA, modifications to RNA do not lead to mutations. However, the biological properties of RNA provide unique opportunities for using it as a biomarker. Compared with DNA, RNA is not usually as densely folded, so it may be more susceptible to reaction with lipid peroxidation products. Also, RNA exists in both the nucleus and cytoplasm, which makes RNA a potentially more sensitive biomarker for oxidative stress than DNA. For example, the lipid peroxidation products produced by the COX-2 enzyme, which resides mostly on the inside of the nuclear membrane, could covalently modify both DNA and RNA. However, the lipid peroxidation products produced by lipoxygenases or reactive oxygen species in the cytoplasm would be primarily captured by RNA. In addition, there are many species of RNA, e.g., mRNA, tRNA, and ribozymes, and they all have their unique cellular functions. Therefore, RNA-adduct formation could interfere with the normal function of mRNA and induce epigenetic responses. For example, it was reported that various RNA-binding proteins are involved in many important biological pathways (24-26). Adduct formation could interfere with the binding between RNA and its binding proteins. Also, the catalytic effects of ribozymes might be abolished by adduct formation. Moreover, the RNA mononucleoside adducts themselves could be toxic to cells and induce apoptosis.

In the present study, the reaction between guanosine (Guo) and ONE was carried out, and the products were characterized using LC-MS ${ }^{n}$ and NMR spectroscopy. This reaction produced four ethano-adducts and one etheno-adduct of guanosine (HzGuo). These Guo adducts were very similar to their dGuo counterparts. The reaction between ONE and yeast tRNA also produced HeGuo. Finally, we were able to detect and quantify HeGuo in RIES cells.

\section{Materials and Methods}

\section{Materials}

Guanosine (Guo), 3-( $N$-morpholino)propanesulfonic acid (MOPS), ammonium acetate, dimethyl sulfoxide- $d_{6}\left(\right.$ DMSO- $\left.d_{6}\right)$, deuterium oxide $\left(\mathrm{D}_{2} \mathrm{O}\right)$ and trimethylsilane (TMS) were

\footnotetext{
${ }^{1}$ Pollack, M., Yang I.-Y., Kim, H.-Y., Blair, I.A., and Moriya, M. Submitted to Nucleic Acids Res.
} 
purchased from Sigma Chemical Co. (St. Louis, MO). $\left[{ }^{15} \mathrm{~N}\right]$-Guo was purchased from Medical Isotopes, Inc. (Pelham, NH). Yeast tRNA was purchased from Invitrogen Inc. (Carlsbad, California). RNase (DNase free) and shrimp alkaline phosphatase (SAP) were obtained from Roche Applied Science, Inc. (Indianapolis, IN). Phosphodiesterase was purchased from Worthington Biochemical Corporation. Supelclean LC-18 SPE columns were acquired from Supelco Inc. (Bellefonte, PA). HPLC-grade water, hexane and acetonitrile were obtained from Fisher Scientific Co. (Fair Lawn, NJ). Gases were supplied by BOC Gases (Lebanon, NJ).

\section{NMR}

The ${ }^{1} \mathrm{H}$ NMR spectra were measured at $25^{\circ} \mathrm{C}$ using a Bruker DMX-400 (wide bore) instrument equipped with a $5 \mathrm{~mm}$ inverse proton probe. The sample of adduct $\mathrm{B}$ was dissolved in 600 $\mu \mathrm{L}$ of DMSO- $d_{6}$, and the residual proton signal of DMSO was used as a reference in the proton spectrum. Acquisition conditions were as follows: spectral width (SW) of $6775 \mathrm{~Hz}, 30^{\circ}$ pulse flip angle (PW), 64K data points (SI), and 64 scans. The ${ }^{1} \mathrm{H}-{ }^{1} \mathrm{H}$ two-dimensional correlation spectroscopy (COSY) spectrum was obtained with an SW1 and SW2 of $5200 \mathrm{~Hz}, 2 \mathrm{~K} \mathrm{SI} 2,512$ experiments zerofilled to $1 \mathrm{~K}$, and 64 scans. Data were processed with a sinebell window.

\section{Mass Spectrometry}

Data were acquired on a Finnigan LCQ ion trap mass spectrometer (Thermo Electron Corp., San Jose, CA) equipped with an atmospheric pressure chemical ionization (APCI) or electrospray ionization (ESI) source in positive ion mode. Instrument conditions for APCI mode were as follows: vaporizer temperature at $450^{\circ} \mathrm{C}$, heated capillary temperature at $150^{\circ}$ $\mathrm{C}$, with a discharge current of $5 \mu \mathrm{A}$ applied to the corona needle. Nitrogen was used as the sheath ( $80 \mathrm{psi}$ ) and auxiliary (5 arbitrary units) gas to assist with nebulization. Instrument conditions for the ESI mode were as follows: capillary temperature at $200{ }^{\circ} \mathrm{C}$, spray voltage of $4.5 \mathrm{kV}$ applied to the electrospray needle. Nitrogen was used as the sheath ( $80 \mathrm{psi})$ and auxiliary (20 psi) gas to assist with nebulization. Full scanning analyses were performed in the range of $\mathrm{m} / z 100-600$. Collision-induced dissociation (CID) experiments coupled with multiple tandem mass Spectrometry $\left(\mathrm{MS}^{\mathrm{n}}\right)$ employed argon as the collision gas. The relative collision energy was set at $20-40 \%$ of the maximum.

The quantification data were acquired on an Applied Biosystems API4000 triple quadrupole mass spectrometer (Foster City, CA) equipped with an ESI turboionspray source in positive ion mode. The operating conditions were as follows: source temperature at $550{ }^{\circ} \mathrm{C}$, spray voltage at $4.5 \mathrm{kV}$, collision cell exit potential at $10 \mathrm{~V}$, collision energy at $23 \mathrm{~V}$, the collision gas pressure at 6 psi and curtain gas at $20 \mathrm{psi}$, and Gas 1 and Gas 2 at $30 \mathrm{psi}$ and $10 \mathrm{psi}$, respectively.

\section{Liquid Chromatography}

Chromatography was performed using a Waters Alliance 2690 HPLC system (Waters Corp., Milford, MA). Gradient elutions were all performed in the linear mode. Gradient systems 1, 2, 3, and 5 employed a Phenomenex Luna C8 column $(250 \mathrm{~mm} \times 4.6 \mathrm{~mm}$ i.d., $5 \mu \mathrm{m}$; Phenomenex, Inc., Torrance, CA) at a mobile phase flow rate of $1 \mathrm{~mL} / \mathrm{min}$. Gradient system 4 employed a Phenomenex Luna C18(2) column (150 $\mathrm{mm} \times 2 \mathrm{~mm}$ i.d., $3 \mu \mathrm{m}$; Phenomenex, Inc., Torrance, CA) at a flow rate of $0.2 \mathrm{~mL} / \mathrm{min}$. Gradient system 6 employed the Phenomenex Luna $\mathrm{C} 8$ column with the mobile phase flow rates detailed below. LC-UV/MS experiments were performed using a Hitachi L-4200 UV detector at $236 \mathrm{~nm}$ for adducts analysis and 260 $\mathrm{nm}$ for RNA base analysis. For systems 1-3, solvent A was $5 \mathrm{mM}$ ammonium acetate in water and solvent B was $5 \mathrm{mM}$ ammonium acetate in acetonitrile. For system 1, the gradient conditions were as follows: $16 \% \mathrm{~B}$ at $0 \mathrm{~min}, 16 \% \mathrm{~B}$ at $40 \mathrm{~min}, 60 \% \mathrm{~B}$ at $41 \mathrm{~min}, 60 \% \mathrm{~B}$ at 55 $\mathrm{min}$, and $16 \% \mathrm{~B}$ at $56 \mathrm{~min}$, followed by a 10 min equilibration period. For system 2 , the gradient conditions were as follows: $20 \% \mathrm{~B}$ at $0 \mathrm{~min}, 20 \% \mathrm{~B}$ at $25 \mathrm{~min}, 60 \% \mathrm{~B}$ at $26 \mathrm{~min}, 60 \% \mathrm{~B}$ at 36 
min, and $20 \% \mathrm{~B}$ at $37 \mathrm{~min}$, followed by a 10 min equilibration period. For system 3 , the gradient conditions were as follows: $6 \% \mathrm{~B}$ at $0 \mathrm{~min}, 6 \% \mathrm{~B}$ at $3 \mathrm{~min}, 15 \% \mathrm{~B}$ at $10 \mathrm{~min}, 15 \% \mathrm{~B}$ at $55 \mathrm{~min}$, $80 \% \mathrm{~B}$ at $57 \mathrm{~min}, 80 \% \mathrm{~B}$ at $65 \mathrm{~min}$, and $6 \% \mathrm{~B}$ at $67 \mathrm{~min}$, followed by a $10 \mathrm{~min}$ equilibration period. For system 4 , solvent A was $0.02 \%$ formic acid in water and solvent B was acetonitrile. The gradient conditions were as follows: $15 \% \mathrm{~B}$ as $0 \mathrm{~min}, 50 \% \mathrm{~B}$ at $15 \mathrm{~min}, 90 \% \mathrm{~B}$ at $16 \mathrm{~min}$, $90 \% \mathrm{~B}$ at $22 \mathrm{~min}, 15 \%$ B at $23 \mathrm{~min}$, followed by an $8 \mathrm{~min}$ equilibration. For system 5, solvent $\mathrm{A}$ was water and solvent $\mathrm{B}$ was acetonitrile. The gradient conditions were as follows: $0 \% \mathrm{~B}$ at $0 \mathrm{~min}, 0 \% \mathrm{~B}$ at $3 \mathrm{~min}, 13 \% \mathrm{~B}$ at $15 \mathrm{~min}, 100 \% \mathrm{~B}$ at $20 \mathrm{~min}, 100 \% \mathrm{~B}$ at $22 \mathrm{~min}$, and $0 \% \mathrm{~B}$ at $25 \mathrm{~min}$, followed by equilibration for $5 \mathrm{~min}$. For system 6 , solvent A was $0.02 \%$ formic acid in water and solvent $\mathrm{B}$ was acetonitrile. The gradient conditions were as follows: $30 \% \mathrm{~B}$ with a flow rate $0.5 \mathrm{~mL} / \mathrm{min}$ at $0 \mathrm{~min}, 60 \% \mathrm{~B}$ with a flow rate of $0.5 \mathrm{~mL} / \mathrm{min}$ at $13 \mathrm{~min}, 100 \% \mathrm{~B}$ with a flow rate of $1.0 \mathrm{~mL} / \mathrm{min}$ at $16 \mathrm{~min}, 100 \%$ B with flow rate $1.0 \mathrm{~mL} / \mathrm{min}$ at $25 \mathrm{~min}, 30 \%$ B with a flow rate of $1.0 \mathrm{~mL} / \mathrm{min}$ at $28 \mathrm{~min}, 30 \%$ B with a flow rate of $1.0 \mathrm{~mL} / \mathrm{min}$ at $35 \mathrm{~min}$, followed by equilibration for $2 \mathrm{~min}$.

\section{Synthesis of 4-Oxo-2(E)-nonenal}

4-Hydroxy-2(E)-nonenal diethyl acetal was oxidized with activated $\mathrm{MnO}_{2}$ as described by Esterbauer and Weger (27). The resulting 4-oxo-2(E)-nonenal diethyl acetal was then hydrolyzed by citric acid/ $\mathrm{HCl}$ as described previously (11) and purified by flash chromatography on silica. It was judged to be $>99 \%$ pure based on its NMR spectrum and HPLC analysis.

\section{Reaction of 4-Oxo-2(E)-nonenal with guanosine}

A solution of ONE (770 $\mu \mathrm{g}, 5.0 \mu \mathrm{mol})$ in ethanol $(20 \mu \mathrm{L})$ was added to Guo $(267 \mu \mathrm{g}, 1.0$ $\mu \mathrm{mol})$ in water $(250 \mu \mathrm{L})$, which had a pH of 5.5. The final concentrations of ONE and Guo were $18.5 \mathrm{mM}$ and $3.7 \mathrm{mM}$ respectively. The reaction mixture was sonicated for $15 \mathrm{~min}$ at room temperature and incubated at $37^{\circ} \mathrm{C}$ or $60^{\circ} \mathrm{C}$ for $24 \mathrm{~h}$, after which it was extracted twice with $200 \mu \mathrm{L}$ hexane to remove excess ONE. Finally the sample was centrifuged at $5000 \mathrm{rpm}$ for $10 \mathrm{~min}$, and the supernatants were analyzed by LC-MS using gradient system 3 . The reaction was conducted in MOPS buffer (100 mM, pH 7.4) and in phosphate buffer (100 mM, pH 7.4). Very similar results were obtained but the yields were slightly lower.

\section{Preparation of Adducts $A_{1 a}$ and $A_{1 b}$ for LC-MS Analysis}

A solution of ONE ( $7.7 \mathrm{mg}, 0.05 \mathrm{mmol}$ ) in $200 \mu \mathrm{L}$ of ethanol was added to guanosine ( 2.83 $\mathrm{mg}, 0.01 \mathrm{mmol}$ ) in $2.0 \mathrm{~mL}$ of water. After sonication for $20 \mathrm{~min}$, the reaction mixture was incubated at $37^{\circ} \mathrm{C}$ for $24 \mathrm{~h}$. The reaction product was isolated by preparative HPLC. Chromatography was conducted using gradient system 1 . Reaction products were collected between 20.0 and $40.0 \mathrm{~min}$ by monitoring the UV response at $236 \mathrm{~nm}$. Fractions containing primarily $\mathrm{A}_{1 \mathrm{a}}$ or $\mathrm{A}_{1 \mathrm{~b}}$ were concentrated under nitrogen at room temperature. Adduct $\mathrm{A}_{1 \mathrm{a}}$ had a retention time of $23.3 \mathrm{~min}$ under these conditions, and adduct $\mathrm{A}_{1 \mathrm{~b}}$ had a retention time of $25.3 \mathrm{~min}$.

\section{Dehydration of Adducts $A_{1 a}$ and $A_{1 b}$}

HPLC-purified adducts $\mathrm{A}_{1 \mathrm{a}}$ or $\mathrm{A}_{1 \mathrm{~b}}$ were dissolved in water/acetonitrile $(100 \mu \mathrm{L}, 84: 16 \mathrm{v} / \mathrm{v})$ and then mixed with $100 \mathrm{mM}$ Chelex-treated MOPS buffer $(100 \mu \mathrm{L})$ containing $150 \mathrm{mM} \mathrm{NaCl}$ at $\mathrm{pH} 3.0,7.0$, or 9.0. The solutions were vortex-mixed for $2 \mathrm{~min}$ then maintained at $37^{\circ} \mathrm{C}$ or $60^{\circ} \mathrm{C}$. Samples were incubated for different times and a portion of each sample $(50 \mu \mathrm{L})$ was then analyzed by LC-UV using gradient system 2 . One sample (at $60^{\circ} \mathrm{C}, \mathrm{pH} 7.4$ for $4 \mathrm{~h}$ ) was analyzed by LC-MS using gradient system 3 on the Finnigan LCQ. 


\section{Preparation of Adduct B}

A solution of ONE ( $7.7 \mathrm{mg}, 0.05 \mathrm{mmol})$ in $200 \mu \mathrm{L}$ of ethanol was added to Guo $(2.83 \mathrm{mg}, 0.01$ $\mathrm{mmol}$ ) in $2.0 \mathrm{~mL}$ of water. The reaction mixture was sonicated for $20 \mathrm{~min}$, incubated at $37^{\circ} \mathrm{C}$ for $24 \mathrm{~h}$, and then $60^{\circ} \mathrm{C}$ for $6 \mathrm{~h}$. Adduct B was isolated using gradient system 2, by monitoring the UV absorbance at $236 \mathrm{~nm}$. The fraction, which eluted between 20.0 and $21.2 \mathrm{~min}$, was concentrated under nitrogen at room temperature. The purity of the collected fraction was checked by LC-UV/MS. Fractions containing pure adduct B were combined, concentrated under reduced pressure, and dried under vacuum. To prepare the $\left[{ }^{15} \mathrm{~N}\right]$-labeled adduct $\mathrm{B}$, the same procedure was carried out using $\left[{ }^{15} \mathrm{~N}_{5}\right]$-Guo and ONE as starting materials.

\section{Reaction of 4-Oxo-2(E)-nonenal with yeast tRNA}

A solution of ONE ( $1.0 \mathrm{mg}, 6.5$ ( $\mu \mathrm{mol})$ in $68 \mu \mathrm{L}$ ethanol was added to $200 \mu \mathrm{g}$ yeast tRNA in $250 \mu \mathrm{L}$ water at a $\mathrm{pH}$ of 5.5 . The reaction mixture was incubated at $37^{\circ} \mathrm{C}$ for $24 \mathrm{~h}$, after which it was extracted twice with $200 \mu \mathrm{L}$ hexane to remove excess ONE. The tRNA was then precipitated and hydrolyzed as described below. $\left[{ }^{15} \mathrm{~N}\right]$-labeled adduct $\mathrm{B}$ internal standard was added, and solid phase extraction (SPE) was performed as described below in order to enrich for adduct B. After SPE extraction, the sample was analyzed with LC-MS/MS using gradient system 4 and multiple reaction monitoring (MRM) (described below).

\section{Cell culture}

RIES cells were obtained from Dr. R.N. DuBois (Vanderbilt University). Cells were grown on plastic dishes in Dulbecco's modified Eagle's medium with 10\% FBS (Summit, Fort Collins, CO), 4,500 mg/L D-glucose, and 100,000 units/liter streptomycin until almost confluent. The cells were not synchronized so potential effects of cell cycle on RNA expression would be random. Cells were collected as described previously when they reached $90 \%$ confluency (10). There was a total of $1 \times 10^{6}$ cell on each plate.

\section{RNA Extraction, Hydrolysis, and Solid Phase Extraction of Adduct B}

RNA from 3 plates of RIES cells ( $3 \times 10^{6}$ cells) was extracted using Ambion RNAqueous Kit (Austin, TX). RNA was precipitated and dissolved in $200 \mu \mathrm{L}$ of $2 \mathrm{mM}$ Tris $/ 20 \mathrm{mM} \mathrm{MgCl}$, $\mathrm{pH}$ 7.4. DNase-free RNase $(2.5 \mu \mathrm{g})$ was added, the sample was incubated at $60^{\circ} \mathrm{C}$ for $1 \mathrm{~h}$ and then at $37{ }^{\circ} \mathrm{C}$ for an additional $1 \mathrm{~h}$. At the end of the incubation, $30 \mu \mathrm{L} 0.2 \mathrm{M}$ glycine buffer (pH 10) and phosphodiesterase (0.5 units) were added, and the sample was incubated at $37^{\circ}$ $\mathrm{C}$ for $2 \mathrm{~h}$. Next, SAP (15 units), $30 \mu \mathrm{L}$ 10x SAP buffer, and $30 \mu \mathrm{L}$ of $50 \mathrm{mM}$ Tris-HCL pH 7.4 were added, and the sample was incubated for $2 \mathrm{~h}$. Finally, the sample was filtered through a $0.2 \mu \mathrm{m}$ Costar cartridge before further analysis. At this time, an aliquot of hydrolyzed RNA was removed for LC-UV RNA base analysis (described below). After adding internal standard, the remaining sample was applied to Supelclean LC-18 SPE columns that had been preconditioned by pre-washing with acetonitrile $(18 \mathrm{~mL})$ followed by water $(18 \mathrm{~mL})$. After sample loading, the column was washed with water $(4 \mathrm{~mL})$ and methanol/water mixture $(1 \mathrm{~mL}, 5: 95$ $\mathrm{v} / \mathrm{v})$. Finally, the adduct was eluted with acetonitrile/water mixture $(6 \mathrm{~mL}, 1: 1 \mathrm{v} / \mathrm{v})$ and dried under nitrogen

\section{RNA Base Analysis}

RNA hydrolysis products were analyzed with HPLC gradient system 5 and at a UV wavelength $260 \mathrm{~nm}$. Quantitation of RNA bases was achieved through constructing standard curves of known amounts of adenosine, cytidine, guanosine, and uridine in the range of $0.005 \mathrm{mg} / \mathrm{mL}$ to $0.25 \mathrm{mg} / \mathrm{mL}$. 


\section{MS Analysis of Adduct B}

The sample was re-dissolved in an acetonitrile/water mixture ( $200 \mu \mathrm{L}, 10: 90 \mathrm{v} / \mathrm{v})$ and analyzed by LC-MRM/MS using gradient system 4 for the nucleoside and tRNA adducts and gradient system 6 for the RIES cell RNA-adducts. For the MRM analysis, parent ions were monitored for the protonated molecule $\left(\mathrm{MH}^{+}\right)$of adduct $\mathrm{B}$ and for its $\left[{ }^{15} \mathrm{~N}_{5}\right]$-internal standard. Product ions were monitored that corresponded to the loss of the ribose moiety from adduct $\mathrm{B}$ $\left(\mathrm{BH}_{2}{ }^{+}\right)$and from its corresponding $\left[{ }^{15} \mathrm{~N}_{5}\right]$-internal standard. The following transitions were monitored: $m / z 420 \rightarrow m / z 288$ (endogenous adduct $\mathrm{B}$ ) and $\mathrm{m} / \mathrm{z} 425 \rightarrow m / z 293\left(\left[{ }^{15} \mathrm{~N}_{5}\right]\right.$-internal standard). Quantitation was performed from standard curves constructed by the ratio of known amounts of authentic standards and internal standards. Adduct levels were normalized to the amount of RNA as detected in the RNA base analysis described above.

\section{Results}

\section{Reaction of 4-Oxo-2(E)-nonenal with Guanosine}

Using gradient system 3, LC-UV/MS analysis of the products from the reaction between Guo and ONE at $37^{\circ} \mathrm{C}$ for $24 \mathrm{~h}$ revealed five major compounds with $\mathrm{MH}^{+}$ions at $\mathrm{m} / z 438$ (adducts $\mathrm{A}_{1 \mathrm{a}}, \mathrm{A}_{1 \mathrm{~b}}, \mathrm{~A}_{2}$ and $\mathrm{A}_{3}$ ) and $m / z 420$ (adduct $\mathrm{B}$ ) (Figure 1). The UV chromatogram also confirmed the formation of five adducts together with residual Guo. When the reaction was heated at 60 ${ }^{\circ} \mathrm{C}$ for $24 \mathrm{~h}$, the magnitudes ofthe UV signals for adducts $\mathrm{A}_{1 \mathrm{a}}, \mathrm{A}_{1 \mathrm{~b}}, \mathrm{~A}_{2}$ and $\mathrm{A}_{3}$ were reduced considerably with a concomitant increase in the magnitude of the UV signal for adduct $B$ (Figure 2).

\section{LC-MS Analysis of Adducts $A_{1 a}, A_{1 b}, A_{2}, A_{3}$ and $B$}

The ESI-MS spectrum for adduct $\mathrm{A}_{1 \mathrm{a}}$ showed an intense $\mathrm{MH}^{+}$at $\mathrm{m} / z 438$ and a sodiated ion $[\mathrm{MNa}]^{+}$at $\mathrm{m} / \mathrm{z} 460 . \mathrm{MS}^{2}$ analysis of $m / z 438$ resulted in a $\mathrm{BH}_{2}{ }^{+}$ion at $m / z 306 . \mathrm{BH}_{2}{ }^{+}$ion can lose a water to produce an ion at $\mathrm{m} / \mathrm{z} 288$. Further fragmentation of $\mathrm{m} / \mathrm{z} 288$ gives $\mathrm{m} / \mathrm{z}, 190$ (Supplementary Figure 1). Adducts $\mathrm{A}_{1 \mathrm{~b}}, \mathrm{~A}_{2}$, and $\mathrm{A}_{3}$ produced the same fragmentation pattern. Adduct $\mathrm{B}$ showed a MH ${ }^{+}$at $\mathrm{m} / \mathrm{z} 420$ in the ESI-MS spectrum. $\mathrm{MS}^{2}$ analysis of this ion generated the $\mathrm{BH}_{2}{ }^{+}$ion at $m / z$ 288. $\mathrm{MS}^{3}$ analysis of $m / z, 288$ again produced an ion with $\mathrm{m} / z, 190$ (Supplementary Figure 2). These data were consistent with the proposed reaction scheme (Scheme I) that adduct $\mathrm{B}$ was a dehydration product of adducts $\mathrm{A}_{1 \mathrm{a}}, \mathrm{A}_{1 \mathrm{~b}}, \mathrm{~A}_{2}$, and $\mathrm{A}_{3}$.

\section{UV Analysis of Adduct B}

The UV spectrum of adduct $\mathrm{B}$ was very similar to that of the corresponding adduct formed between ONE and dGuo, with a $\lambda_{\max }$ at $229 \mathrm{~nm}$ at $\mathrm{pH} 7$. The $\lambda_{\max }$ was shifted to $236 \mathrm{~nm}$ at pH 13 and to $226 \mathrm{~nm}$ at pH 1 (Supplementary Figure 3).

\section{NMR Analysis of Adduct B}

Assignments were made on the basis of chemical shifts and proton-proton couplings (Table 1 and Figure 3) together with COSY correlations (Figure 4). In the ${ }^{1} \mathrm{H}$ NMR spectrum, besides the aromatic $\mathrm{AB}$ system of the Guo moiety, there was an additional aromatic proton singlet at $7.14 \mathrm{ppm}(\mathrm{H}-6)$. This proton showed COSY correlations with the methylene protons at H-1" (4.12 ppm). These data were consistent with the presence of an olefinic bond between C- 6 and C-7. The NH signal corresponding to H-5 appeared as a doublet at 12.25 ppm coupled to H-6 $(J=2.3 \mathrm{~Hz})$. However the integration of this peak was less than one proton. There was an extra singlet at $8.32 \mathrm{ppm}$, which is most likely, the C-9 enol proton resulting from the shift of H-5 proton to the C-9 carbonyl group (Table 1). H-6 appe ared at $7.14 \mathrm{ppm}$ as a broad singlet coupled to $\mathrm{H}-5$. The triplet at $2.57 \mathrm{ppm}$ was assigned to the methylene protons at $\mathrm{H}-3$ " because of its chemical shift and its multiplicit y. The COSY spectrum also showed the correlations between the H-3" protons with the H-4" protons ( $1.51 \mathrm{ppm}$ ). Similarly, the multiplets at 1.28 
ppm were assigned to the four methylene protons at $\mathrm{H}-4$ " and $\mathrm{H}-5$ ". The triplet at $0.87 \mathrm{ppm}$ was assigned to the methyl group at C-7". The COSY spectrum also showed correlations between the $\mathrm{H}-1^{\prime}$ proton $(5.79 \mathrm{ppm})$ and the proton at $\mathrm{H}-2^{\prime}(4.45 \mathrm{ppm})$, the $\mathrm{H}-2^{\prime}$ protons with the hydroxyl at C-2' (5.46 ppm), the H-3' protons with the hydroxyl at C-3' (5.13 ppm) and with the H-4' proton (3.92 ppm), the H-4' proton with the H-5' protons ( 3.55 and $3.65 \mathrm{ppm}$ ) and the $\mathrm{H}-5^{\prime}$ protons with the hydroxyl at $\mathrm{C}-5^{\prime}$ (5.04 ppm). A deuterium exchange experiment was done to further confirm the assignments of the exchangeable protons. After exchange with $\mathrm{D}_{2} \mathrm{O}$, the NMR signals from the assigned $\mathrm{H}-5, \mathrm{C} 9-\mathrm{OH}$ and $2^{\prime}, 3^{\prime}, 5^{\prime}-\mathrm{OH}$ protons all disappeared (Supplementary Figure 4). This confirmed the structure of adduct B as heptanone-etheno-Guo (HeGuo), 3-(D-erythropentafuranosyl)imidazo-7-(heptane-2"-one)-9-hydroxyl[1,2- $\alpha]$ purine (Figure 3, inset).

\section{Dehydration of Adducts $A_{1 a}$ and $A_{1 b}$}

Time course experiments were performed at $37{ }^{\circ} \mathrm{C}$ and $60{ }^{\circ} \mathrm{C}$ and at $\mathrm{pH} 3.0,7.4$, and 9.0 for adducts $\mathrm{A}_{1 \mathrm{a}}$ and $\mathrm{A}_{1 \mathrm{~b}}$ by measuring the peak areas in the LC-UV spectrum. Both adduct $\mathrm{A}_{1 \mathrm{a}}$ (Figure 5) and adduct $\mathrm{A}_{1 \mathrm{~b}}$ (data not shown) were converted to adduct $\mathrm{B}$ similarly in a temperature- and $\mathrm{pH}$-dependent manner. At higher temperatures, the transformation was faster. Lower $\mathrm{pH}$ also increased the transformation rate. The dehydration of $\mathrm{A}_{1 \mathrm{a}}$ to $\mathrm{B}$ (Supplementary Figure 5) and $A_{1 b}$ to $B$ (data not shown) was confirmed by LC-MS. Adducts $A_{2}$ and $A_{3}$ much more readily dehydrated to adduct $B$ than adducts $A_{1 a}$ and $A_{1 b}$, which made it impossible to prepare pure samples of the individual isomers. This suggested that adducts $A_{1 a}$ and $A_{1 b}$ were the more stable isomeric hemi-ketal adducts (Scheme I) similar to the more stable hemi-ketal adduct identified in the reaction of ONE with dGuo (11).

\section{MS Analysis of the Reaction of 4-0xo-2(E)-nonenal with Yeast tRNA}

Typical chromatograms from LC-ESI/MRM/MS analysis of $0.2 \mathrm{ng} / \mathrm{mL}$ authentic adduct $B$ (HeGuo) and its corresponding $\left[{ }^{15} \mathrm{~N}_{5}\right]$ internal standard are shown in Figure 6 (A and B). $\mathrm{H} \varepsilon$ Guo was quantified using calibration curves obtained with a linear regression analysis of peak area ratios of $\mathrm{H \varepsilon Guo} \mathrm{to} \mathrm{its}\left[{ }^{15} \mathrm{~N}_{5}\right.$ ]-labeled internal standard (Figure 6, C and D); concentrations of $\mathrm{H} \varepsilon \mathrm{Guo}$ were calculated by interpolation from the calculated regression line $y=0.7004 x+0.0264\left(r^{2}=0.998\right)$. HeGuo levels were normalized to the amount of tRNA in the sample. The final quantification of $\mathrm{H} \varepsilon \mathrm{Guo}$ corresponded to 24.4 adducts per $10^{3} \mathrm{normal}$ bases.

\section{MS Analysis of RNA from RIES Cells}

RIES cells were cultured to confluence. RNA was extracted from the cells, hydrolyzed, and analyzed using the same method as described above for tRNA. Typical chromatograms from LC-ESI/MRM/MS analysis of $400 \mathrm{pg} / \mathrm{mL}$ of authentic adduct B (HeGuo) and its corresponding $\left[{ }^{15} \mathrm{~N}_{5}\right]$ internal standard are shown in Figure 7 (A and B). Typical chromatograms obtained from RIES cell RNA for $\mathrm{H \varepsilon Guo} \mathrm{and} \mathrm{its} \mathrm{internal} \mathrm{are} \mathrm{shown} \mathrm{in} \mathrm{Figures} \mathrm{7C} \mathrm{and} \mathrm{7D,} \mathrm{respectively.}$ Concentrations of HeGuo in the RIES cell RNA were calculated by interpolation of the peak area ratios of analyte to internal standard using the calculated regression line $\mathrm{y}=0.1334 \mathrm{x}+$ $0.0169\left(r^{2}=0.998\right)$. HzGuo levels of 7.0 adducts per $10^{6}$ normal bases $( \pm 1.1 ; \mathrm{SD})$ were found $(n=4)$ after normalization for the amount of RNA that was isolated from the RIES cells.

\section{Discussion}

Cellular oxidative stress of polyunsaturated fatty acids leads to the formation of lipid hydroperoxides. The lipid hydroperoxides can then undergo homolytic decomposition to the reactive bifunctional electrophile, ONE, which reacts with DNA bases $(4,11-14)$, peptides (28-30), and proteins (31-33) to form adducts. The reaction between ONE and dGuo is thought to take place through a two-step mechanism involving initial Michael addition of $N^{2}$ to the C-1 
aldehyde. Four major adducts were formed in the reaction: three of them were ethano adducts; one was the dehydrated etheno adduct, HedGuo (11). Although many studies have been conducted to characterize the reactions of bifunctional electrophiles, such as ONE with DNA and proteins, little attention has been paid to their potential reactions with RNA. The present investigation of the reaction between Guo and ONE revealed the formation of five adducts, each of them very similar to adducts formed between dGuo and ONE (11). Adducts $A_{2}$ and $\mathrm{A}_{3}$ were identified as heptanone-ethano-guanosine adducts, and $\mathrm{A}_{1 \mathrm{a}}, \mathrm{A}_{1 \mathrm{~b}}$ as hemi-ketal isomers. Because no interconversion between $A_{1 a}$ and $A_{1 b}$ was observed, $A_{1 a}$ and $A_{1 b}$ are proposed to be the $6(\mathrm{R}), 7(\mathrm{~S})$ and the $6(\mathrm{~S}), 7(\mathrm{R})$ isomers (Scheme I). Adduct $B$ was characterized as the heptanone-etheno-Guo (HeGuo) adduct, 3-(D-erythropentafuranosyl) imidazo-7-(heptane-2"-one)-9-hydroxyl[1,2- $\alpha]$ purine adduct by LC-MS ${ }^{\text {n }}$ (Supplementary Figures 1 and 2) and NMR spectroscopy (Figures 3 and 4). Adduct $A_{1 a}$ was unstable and readily dehydrated to $\mathrm{H} \varepsilon \mathrm{Guo}$ as shown for adduct $\mathrm{A}_{1 \mathrm{a}}$ in Figure 5. The dehydration process was catalyzed by acid. Under alkaline conditions, the rate of dehydration decreased significantly (Figure 5). Overall the Guo adducts with ONE have similar structures and chemical properties to the dGuo adducts. This suggests that the mechanism of formation is very similar (Scheme I) (11-14).

The reaction between yeast tRNA and ONE efficiently produced the same adducts as in nucleoside reactions (Figure 6) showing that adduction of RNA by ONE was feasible. This raised the possibility that ONE adduction would occur in cells. RIES cells that stably express COX-2 were selected as a model cell system because COX-2 is highly expressed in colon cancer tissue and other cancers, but not in normal tissue (35-37). In addition to its role in prostaglandin formation, COX-2 mediates the formation of lipid hydroperoxide-derived DNAadducts (10). In order to assess the formation of RNA-adduct formation in RIES cells, a high sensitivity LC-MS/MS method was developed in order to quantify low pg amounts of $\mathrm{H} \varepsilon$ Guo. Using this method, the adduct abundance in RIES cells was 7.0 adducts per $10^{6}$ normal Guo bases (Figure 7). The similar HedGuo-adduct was present at 2.0 adducts per $10^{7}$ normal bases in the RIES cells under the same conditions (10). Thus, the heptanone-etheno adducts in RNA were approximately 35 times more abundant than the corresponding DNA-adducts.

The increased formation of RNA-adducts is most likely the consequence of a number of factors. First, RNA is present in both the cytoplasm and nucleus, while DNA is only found within the nucleus. Thus, RNA is more accessible to lipid peroxidation products released in both the nucleus and in the cytoplasm. Second, RNA exists in a variety of forms (tRNA, mRNA, ribosomes, ribozymes, microRNAs) with extended structures; in contrast, DNA is typically more densely folded and wrapped around histone proteins. So the various RNA forms would be more susceptible to reaction with bifunctional electrophiles than DNA. Third, RNA-adducts may be less readily repaired than the corresponding DNA-adducts. Besides serving as biomarkers, lipid hydroperoxide-derived RNA-adducts could have a variety of potential biological and toxicological effects, given that RNA is involved in so many diverse cellular functions. For example, mRNA-adduct formation could potentially modulate transcription and translation resulting in altered protein expression.

In summary, we have identified five RNA-adducts formed in the reaction between Guo and ONE. These adducts are very similar to those formed between dGuo and ONE, which suggests that lipid peroxidation can damage RNA in a similar manner to DNA. Detection and quantification of the $\mathrm{H} \varepsilon \mathrm{Guo}$ adduct in RIES cells confirmed this hypothesis. These findings suggest that heptanone-etheno-RNA-adducts in cell culture models and in tissue samples will provide biomarkers of oxidative stress. However, the biological role of these lipid hydroperoxide-derived RNA-adducts awaits further studies. 


\section{Supplementary Material}

Refer to Web version on PubMed Central for supplementary material.

\section{Acknowledgements}

We gratefully acknowledge the support of NIH grant RO1 CA91016 and the editorial assistance of Dr. Michael Pollack.

\section{Abbreviations}

\section{APCI}

atmospheric pressure chemical ionization

bs

broad singlet

CID

collision induced dissociation

$\operatorname{COSY}$

${ }^{1} \mathrm{H}-{ }^{1} \mathrm{H}$ 2D correlation spectroscopy

COX

cyclooxygenase

$\mathbf{D}_{2} \mathbf{O}$

deuterium oxide

d

doublet

DMSO- $d_{6}$

dimethyl sulfoxide- $d_{6}$

EDE

4,5-epoxy-2(E)-decenal

ESI

electrospray ionization

Guo

guanosine

HeGuo

heptanone-etheno-Guo

HedGuo

heptanone-etheno-2'-dGuo

HNE

4-hydroxy-2(E)-nonenal

HPNE

4-hydroperoxy-2(E)-nonenal

LC-MS

liquid chromatography-mass spectrometry 
m

multiplet

$\mathrm{MH}^{+}$

protonated molecule

$\mathbf{M S}^{\mathbf{n}}$

multiple tandem mass spectrometry

MOPS

morpholinopropanesulfonic acid

MRM

multiple reaction monitoring

\section{NMR}

nuclear magnetic resonance

\section{ONE}

4-oxo-2(E)-nonenal

$\mathbf{q}$

quintet

RIES

rat intestinal epithelial cells that stably express COX-2

$\mathbf{S}$

singlet

SAP

shrimp alkaline phosphatase

SPE

solid phase extraction

$\mathbf{t}$

triplet

TIC

total ion current

TMS

trimethylsilane

\section{References}

1. Lee SH, Blair IA. Characterization of 4-oxo-2-nonenal as a novel product of lipid peroxidation. Chem Res Toxicol 2000;13:698-702. [PubMed: 10956056]

2. Lee SH, Oe T, Blair IA. Vitamin C-induced decomposition of lipid hydroperoxides to endogenous genotoxins. Science 2001;292:2083-2086. [PubMed: 11408659]

3. Benedetti A, Comporti M, Esterbauer H. Identification of 4-hydroxynonenal as a cytotoxic product originating from the peroxidation of liver microsomal lipids. Biochim Biophys Acta 1980;620:281296. [PubMed: 6254573]

4. Lee SH, Oe T, Blair IA. 4,5-Epoxy-2(E)-decenal-induced formation of 1,N(6)-etheno-2'deoxyadenosine and 1,N(2)-etheno-2'-deoxyguanosine adducts. Chem Res Toxicol 2002;15:300-304. [PubMed: 11896675] 
5. Lee SH, Oe T, Arora JS, Blair IA. Analysis of Fell-mediated decomposition of a linoleic acid-derived lipid hydroperoxide by liquid chromatography/mass spectrometry. J Mass Spectrom 2005;40:661668. [PubMed: 15739161]

6. Williams MV, Lee SH, Blair IA. Liquid chromatography/mass spectrometry analysis of bifunctional electrophiles and DNA adducts from vitamin C mediated decomposition of 15hydroperoxyeicosatetraenoic acid. Rapid Commun Mass Spectrom 2005;19:849-858. [PubMed: 15723435]

7. Birkenkamp-Demtroder K, Olesen SH, Sorensen FB, Laurberg S, Laiho P, Aaltonen LA, Orntoft TF. Differential gene expression in colon cancer of the caecum versus the sigmoid and rectosigmoid. Gut 2005;54:374-384. [PubMed: 15710986]

8. Wang L, Lu W, Chen YG, Zhou XM, Gu JR. Comparison of gene expression between normal colon mucosa and colon carcinoma by means of messenger RNA differential display. World J Gastroenterol 1999;5:533-534. [PubMed: 11819507]

9. Backert S, Gelos M, Kobalz U, Hanski ML, Bohm C, Mann B, Lovin N, Gratchev A, Mansmann U, Moyer MP, Riecken EO, Hanski C. Differential gene expression in colon carcinoma cells and tissues detected with a cDNA array. Int J Cancer 1999;82:868-874. [PubMed: 10446455]

10. Lee SH, Williams MV, Dubois RN, Blair IA. Cyclooxygenase-2-mediated DNA damage. J Biol Chem 2005;280:28337-28346. [PubMed: 15964853]

11. Rindgen D, Nakajima M, Wehrli S, Xu K, Blair IA. Covalent modifications to 2'-deoxyguanosine by 4-oxo-2-nonenal, a novel product of lipid peroxidation. Chem Res Toxicol 1999;12:1195-1204. [PubMed: 10604869]

12. Lee SH, Rindgen D, Bible RH Jr, Hajdu E, Blair IA. Characterization of 2'-deoxyadenosine adducts derived from 4-oxo-2-nonenal, a novel product of lipid peroxidation. Chem Res Toxicol 2000;13:565-574. [PubMed: 10898588]

13. Rindgen D, Lee SH, Nakajima M, Blair IA. Formation of a substituted 1,N(6)-etheno-2'deoxyadenosine adduct by lipid hydroperoxide-mediated generation of 4-oxo-2-nonenal. Chem Res Toxicol 2000;13:846-852. [PubMed: 10995257]

14. Pollack M, Oe T, Lee SH, Silva Elipe MV, Arison BH, Blair IA. Characterization of 2'-deoxycytidine adducts derived from 4-oxo-2-nonenal, a novel lipid peroxidation product. Chem Res Toxicol 2003;16:893-900. [PubMed: 12870892]

15. Williams MV, Lee SH, Pollack M, Blair IA. Endogenous lipid hydroperoxide-mediated DNA-adduct formation in min mice. J Biol Chem. 200610.1074/jbc.M600178200[Epub ahead of print]

16. Cardona RA, King CM, Redpath JL. Irradiation-induced adduct formation of RNA with carcinogenic arylamine derivatives. Cancer Res 1975;35:2007-2014. [PubMed: 1149020]

17. King CM, Traub NR, Cardona RA, Howard RB. Comparative adduct formation of 4-aminobiphenyl and 2-aminofluorene derivatives with macromolecules of isolated liver parenchymal cells. Cancer Res 1976;36:2374-2381. [PubMed: 1277141]

18. Gaugler BJ, Neumann HG. The binding of metabolites formed from aminostilbene derivatives to nucleic acids in the liver of rats. Chem Biol Interact 1979;24:355-372. [PubMed: 428017]

19. Park KK, Archer MC, Wishnok JS. Alkylation of nucleic acids by N-nitrosodi-n-propyl-amine: evidence that carbonium ions are not significantly involved. Chem Biol Interact 1980;29:139-144. [PubMed: 7353229]

20. Surh YJ, Lai CC, Miller JA, Miller EC. Hepatic DNA and RNA adduct formation from the carcinogen 7-hydroxymethyl-12-methylbenz[a]anthracene and its electrophilic sulfuric acid ester metabolite in preweanling rats and mice. Biochem Biophys Res Commun 1987;144:576-582. [PubMed: 2437917]

21. Reiber DC, Murphy RC. Covalent binding of LTA(4) to nucleosides and nucleotides. Arch Biochem Biophys 2000;79:119-126. [PubMed: 10864449]

22. Hankin JA, Jones DN, Murphy RC. Covalent binding of leukotriene A4 to DNA and RNA. Chem Res Toxicol 2003;16:551-561. [PubMed: 12703973]

23. Sotomayor RE, Washington M, Nguyen L, Nyang' anyi R, Hinton DM, Chou M. Effects of intermittent exposure to aflatoxin B1 on DNA and RNA adduct formation in rat liver: dose-response and temporal patterns. Toxicol Sci 2003;73:329-338. [PubMed: 12700393]

24. Gautrey H, McConnell J, Hall J, Hesketh J. Polarised distribution of the RNA-binding protein Staufen in differentiated intestinal epithelial cells. FEBS Lett 2005;579:2226-2230. [PubMed: 15811346] 
25. Noureddine MA, Qin XJ, Oliveira SA, Skelly TJ, van der Walt J, Hauser MA, Pericak-Vance MA, Vance JM, Li YJ. Association between the neuron-specific RNA-binding protein ELAVL4 and Parkinson disease. Hum Genet 2005;117:27-33. [PubMed: 15827745]

26. Pullmann R Jr, Juhaszova M, Lopez de Silanes L, Kawai T, Mazan-Mamczarz K, Halushka MK, Gorospe M. Enhanced proliferation of cultured human vascular smooth muscle cells linked to increased function of RNA-binding protein HuR. J Biol Chem 2005;280:22819-22826. [PubMed: 15824116]

27. Esterbauer H, Weger W. Uber die wirkungen von aldehyden auf gesunde und maligne zellen, 3 mitt: Synthese von homologen 4-hydroxy-alkenalen, II (Actions of aldehydes on normal and malignant cells III Synthesis of homologous 4-hydroxy-2-alkenals 2). Monatsh Chem 1967;98:1994-2000.

28. Doom JA, Petersen DR. Covalent modification of amino acid nucleophiles by the lipid peroxidation products 4-hydroxy-2-nonenal and 4-oxo-2-nonenal. Chem Res Toxicol 2002;15:1445-1450. [PubMed: 12437335]

29. Oe T, Lee SH, Silva Elipe MV, Arisen BH, Blair IA. A novel lipid hydroperoxide-derived modification to arginine. Chem Res Toxicol 2003;16:1598-1605. [PubMed: 14680374]

30. Jian W, Arora JS, Oe T, Shuvaev VV, Blair IA. Induction of endothelial cell apoptosis by lipid hydroperoxide-derived bifunctional electrophiles. Free Radic Biol Med 2005;39:1162-1176. [PubMed: 16214032]

31. Oe T, Arora JS, Lee SH, Blair IA. A novel lipid hydroperoxide-derived cyclic covalent modification to histone H4. J Biol Chem 2003;278:42098-42105. [PubMed: 12930824]

32. Liu Z, Minkler PE, Sayre LM. Mass spectroscopic characterization of protein modification by 4hydroxy-2-(E)-nonenal and 4-oxo-2-(E)-nonenal. Chem Res Toxicol 2003;16:901-911. [PubMed: 12870893]

33. Yocum AK, Oe T, Yergey AL, Blair IA. Novel lipid hydroperoxide-derived hemoglobin histidine adducts as biomarkers of oxidative stress. J Mass Spectrom 2005;40:754-764. [PubMed: 15827957]

34. Lin D, Lee HG, Liu Q, Perry G, Smith MA, Sayre LM. 4-Oxo-2-nonenal is both more neurotoxic and more protein reactive than 4-hydroxy-2-nonenal. Chem Res Toxicol 2005;18:1219-1231. [PubMed: 16097795]

35. Fujita H, Koshida K, Keller ET, Takahashi Y, Yoshimito T, Namiki M, Mizokami A. Cyclooxygenase-2 promotes prostate cancer progression. Prostate 2002;53:232-240. [PubMed: 12386924]

36. Sano H, Kawahito Y, Wilder RL, Hashiramoto A, Mukai S, Asai K, Kimura S, Kato H, Kondo M, Hla T. Expression of cyclooxygenase-1 and -2 in human colorectal cancer. Cancer Res 1995;55:3785-3789. [PubMed: 7641194]

37. Ranger GS, Thomas V, Jewell A, Mokbel K. Elevated cyclooxygenase-2 expression correlates with distant metastases in breast cancer. Anticancer Res 2004;24:2349-2351. [PubMed: 15330183] 


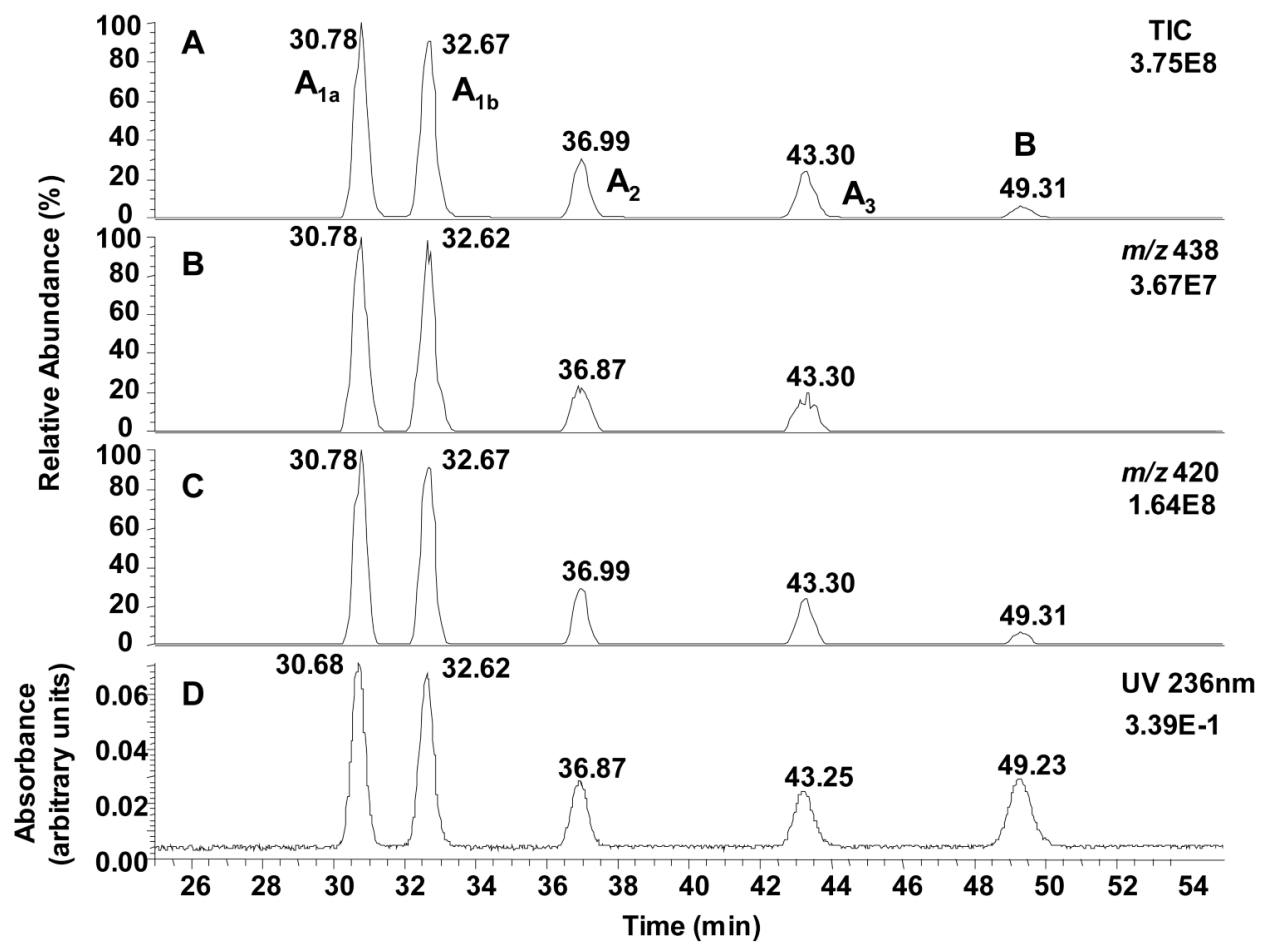

Figure 1.

Analysis of the reaction between ONE and Guo for $24 \mathrm{~h}$ at $37^{\circ} \mathrm{C}$ by concurrent LC-MS and UV detection using gradient system 3. (A) Total ion current (TIC) chromatogram. (B and C). Reconstructed selected ion chromatograms of the $\mathrm{MH}^{+}$of adduct $\mathrm{A}_{1 \mathrm{a}}, \mathrm{A}_{1 \mathrm{~b}}, \mathrm{~A}_{2}$ and $\mathrm{A}_{3}(\mathrm{~m} / \mathrm{z}$ 438), and adduct B ( $\mathrm{m} / \mathrm{z}$ 420). (D) UV absorbance at $236 \mathrm{~nm}$. 


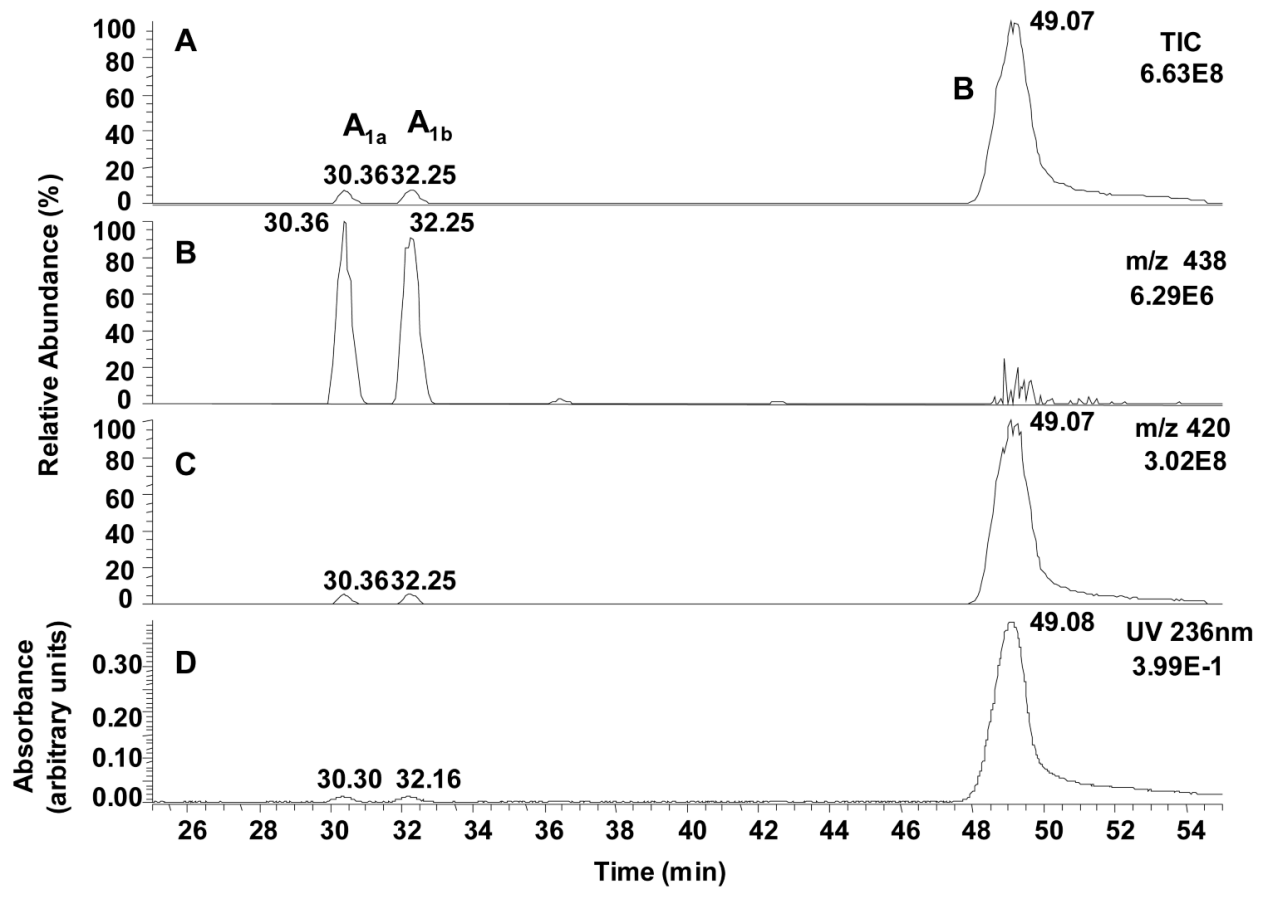

Figure 2.

Analysis of the reaction between ONE and Guo for $24 \mathrm{~h}$ at $37{ }^{\circ} \mathrm{C}$ and then heated for $7 \mathrm{~h}$ at 60 ${ }^{\circ} \mathrm{C}$ by concurrent LC-MS and UV detection using gradient system 3. (A) Total ion current (TIC) chromatogram. (B and C). Reconstructed selected ion chromatograms of the $\mathrm{MH}^{+}$of adduct $\mathrm{A}_{1 \mathrm{a}}, \mathrm{AH}_{1 \mathrm{~b}}, \mathrm{~A}_{2}$ and $\mathrm{A}_{3}(\mathrm{~m} / \mathrm{z} 438)$, and adduct $\mathrm{B}(\mathrm{m} / \mathrm{z} 420)$. (D) $\mathrm{UV}$ absorbance at 236 $\mathrm{nm}$. 


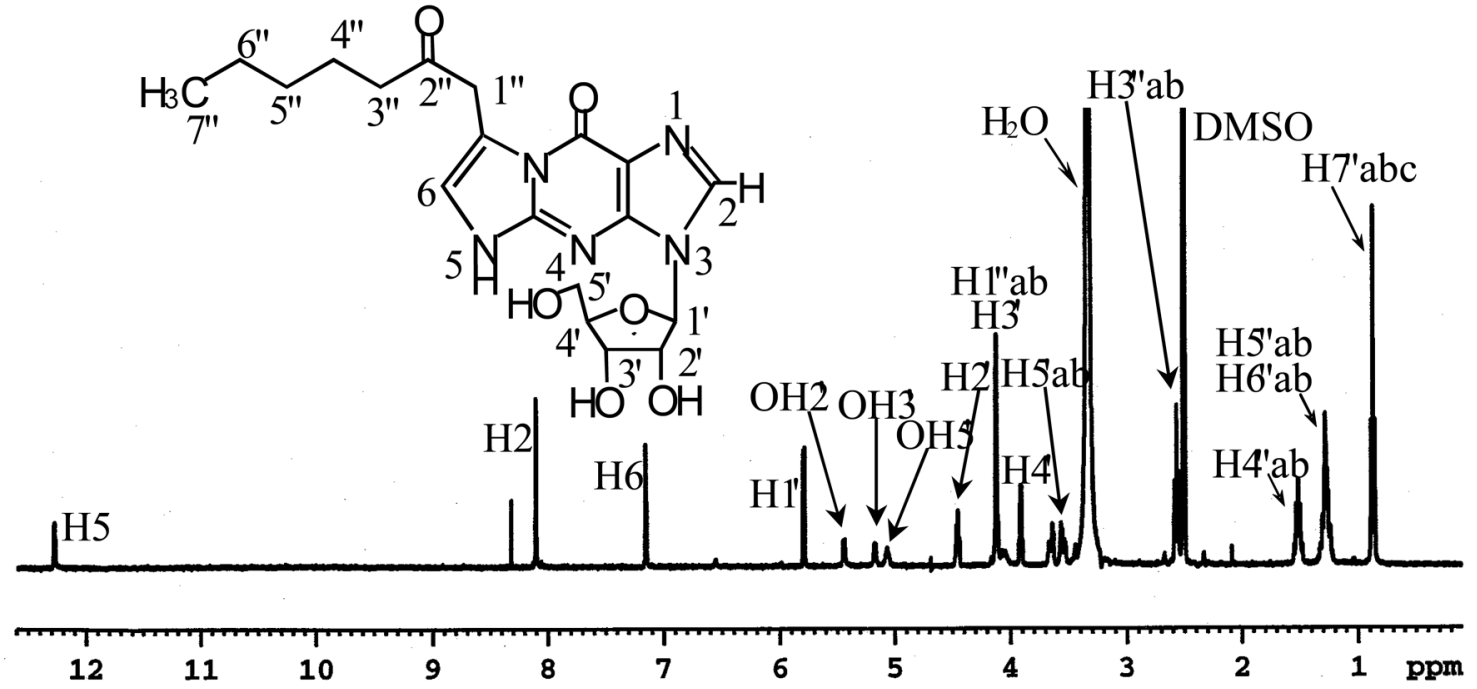

Figure 3.

${ }^{1} \mathrm{H}$ NMR spectrum of adduct B in DMSO- $d_{6}$. The inset shows the structure of adduct B as HeGuo based on NMR data. 


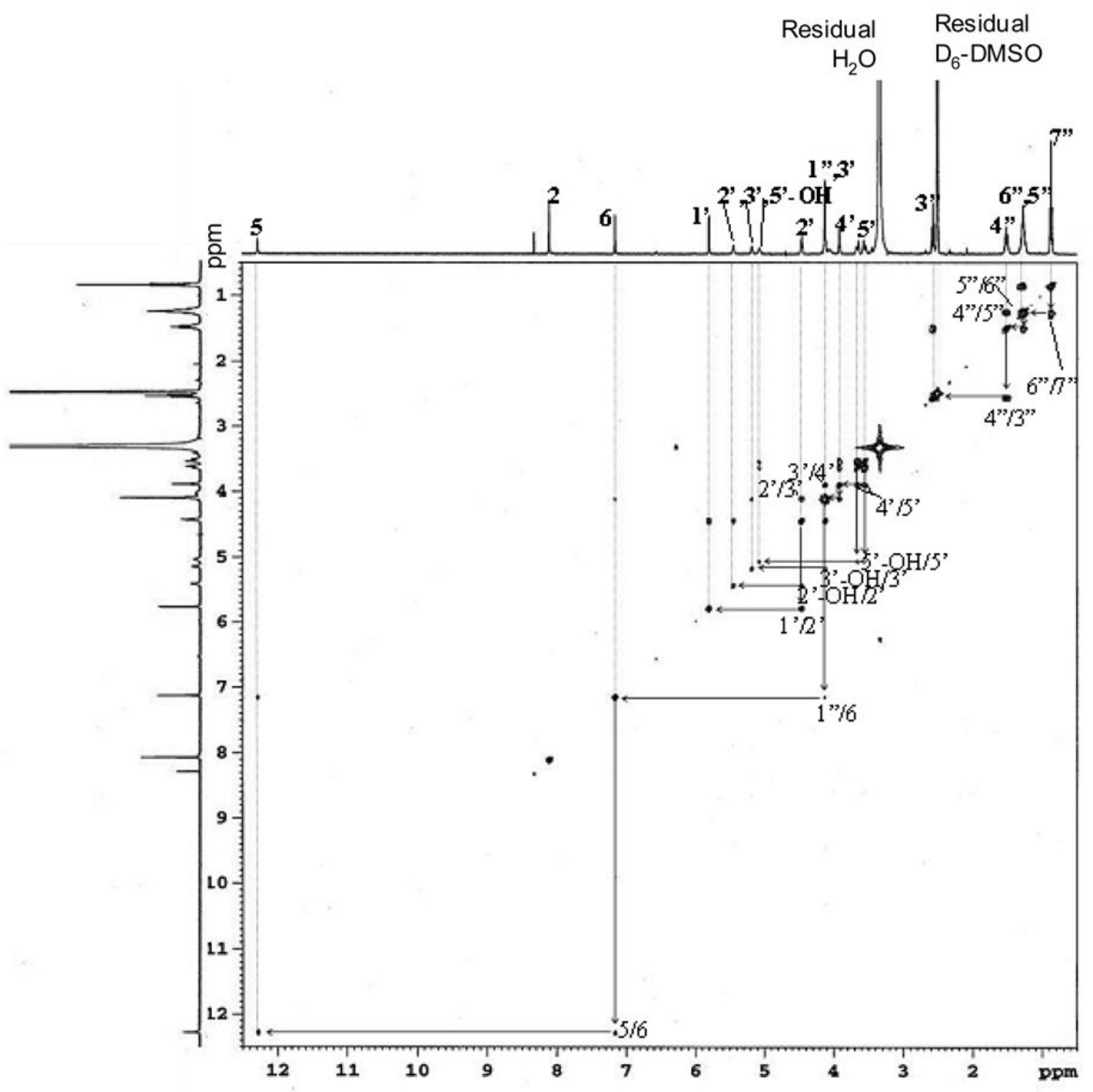

Figure 4.

${ }^{1} \mathrm{H}-{ }^{1} \mathrm{H}$ two-dimensional COSY NMR spectrum of adduct B (HeGuo) in DMSO- $d_{6}$. 


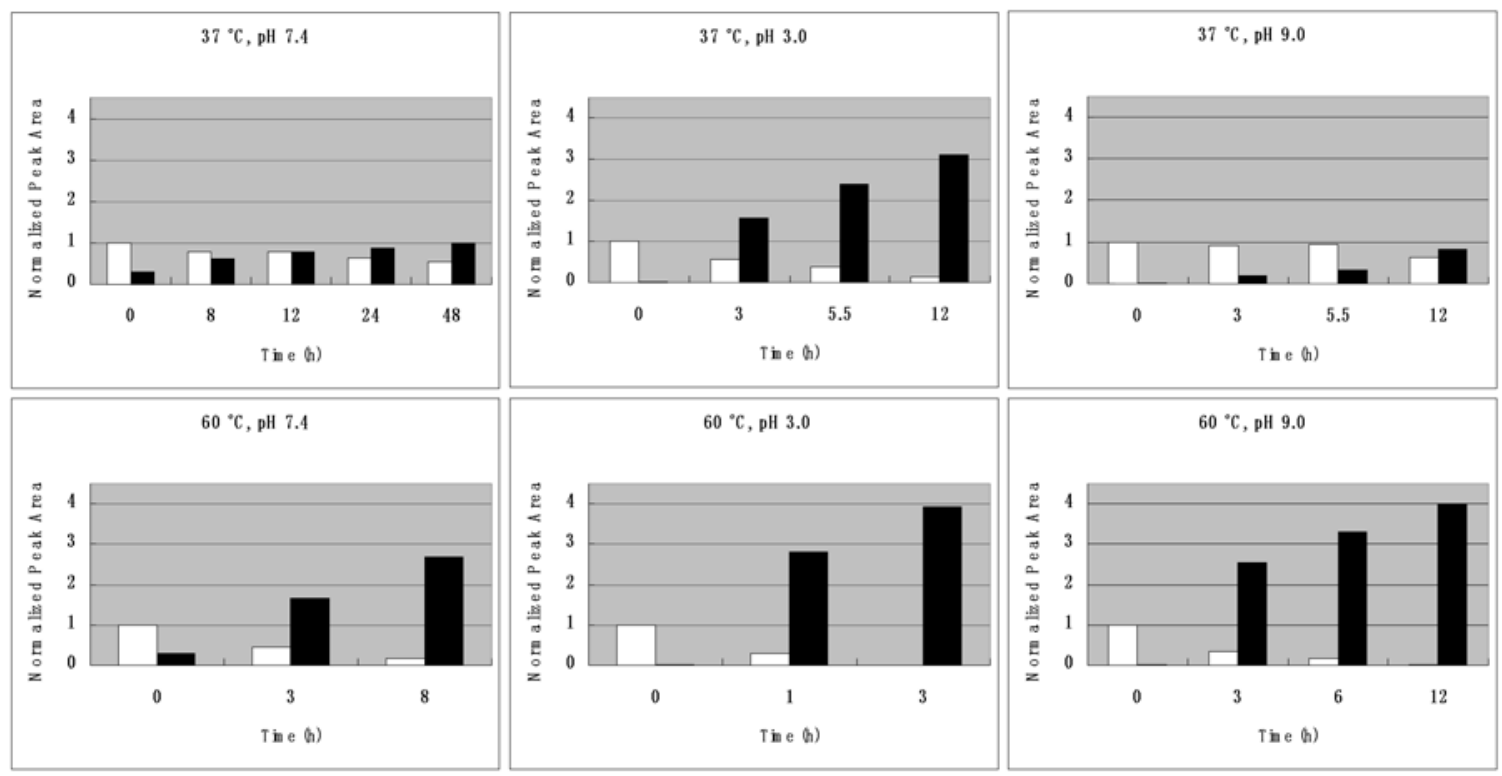

Figure 5.

Time courses for the dehydration of adduct $\mathrm{A}_{1 \mathrm{a}}$ to adduct $\mathrm{B}$ at $37^{\circ} \mathrm{C}$ vs. $60{ }^{\circ} \mathrm{C}$ and at $\mathrm{pH} 3.0$, 7.4 and 9.0 as determined by LC/UV monitoring $236 \mathrm{~nm}$. White bars represent adduct $\mathrm{A}_{1 \mathrm{a}}$. Black bars represent HeGuo. The normalized peak area for peak B was $>1$ because the $\lambda_{\max }$ for adduct B under acidic conditions was $226 \mathrm{nM}$ (Supplementary Figure 3) whereas, the $\lambda_{\text {max }}$ for adduct Ala was $252 \mathrm{nM}$. Results for dehydration of adduct $\mathrm{A}_{1 \mathrm{~b}}$ were essentially identical. 


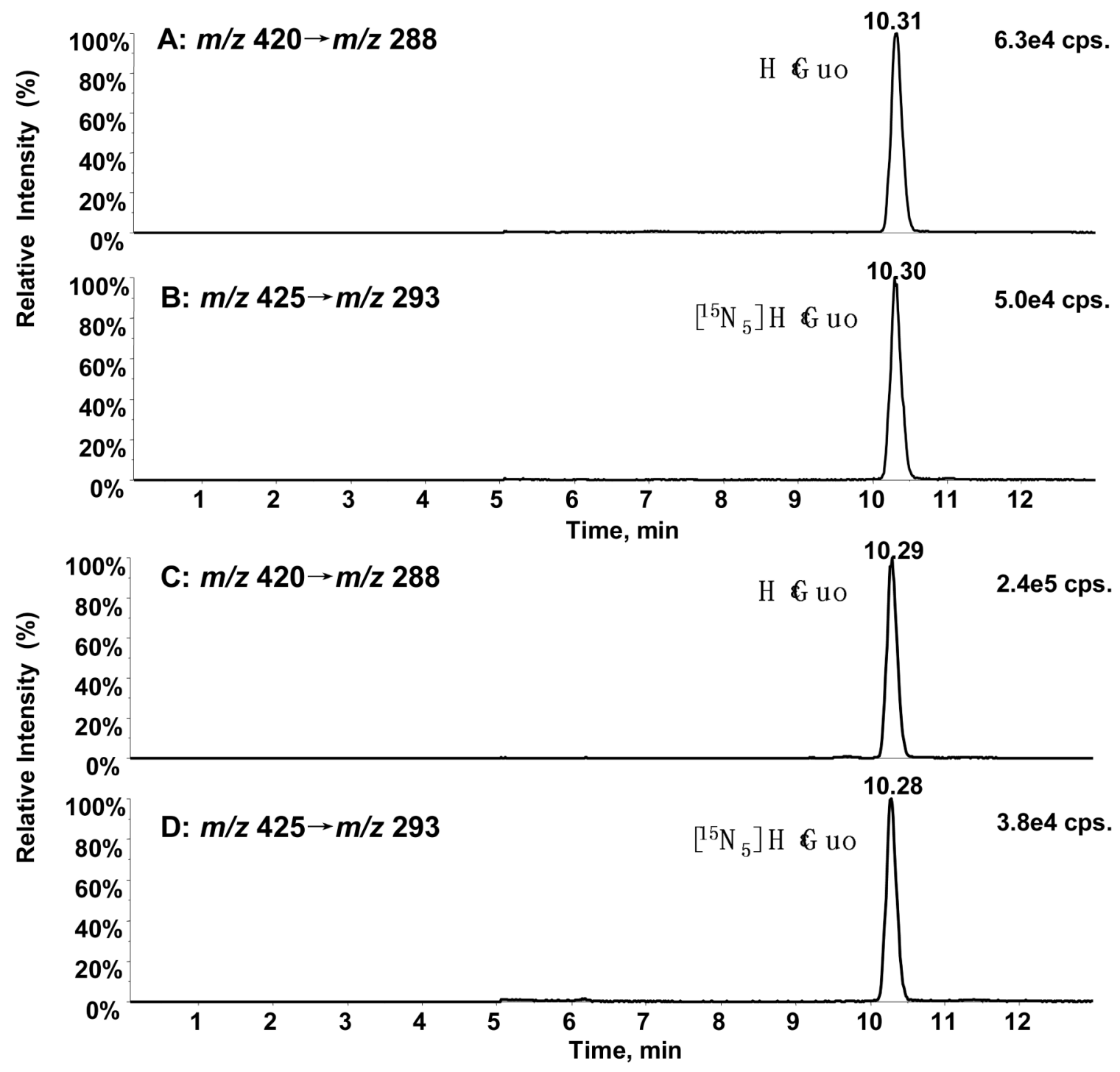

Figure 6.

LC-ESFMRM/MS analysis of HeGuo and its corresponding $\left[{ }^{15} \mathrm{~N}_{5}\right]$ internal standard. (A) Authentic HeGuo standard (200 pg/mL). (B) Internal standard. (C) HeGuo (24.4 adducts per $10^{3}$ normal Guo bases) from yeast tRNA $(200 \mathrm{mg})$ treated with ONE (1.0 mg, 6.5 ( $\left.\mu \mathrm{mol}\right)$. (D). Internal standard for yeast tRNA. Ion chromatograms for $\mathrm{H} \varepsilon \mathrm{Guo}(\mathrm{m} / \mathrm{z} 420 \rightarrow \mathrm{m} / \mathrm{z} 288)$, $\left[{ }^{15} \mathrm{~N}_{5}\right] \mathrm{HzGuo}(\mathrm{m} / \mathrm{z}, 425 \rightarrow m / z, 293)$. 


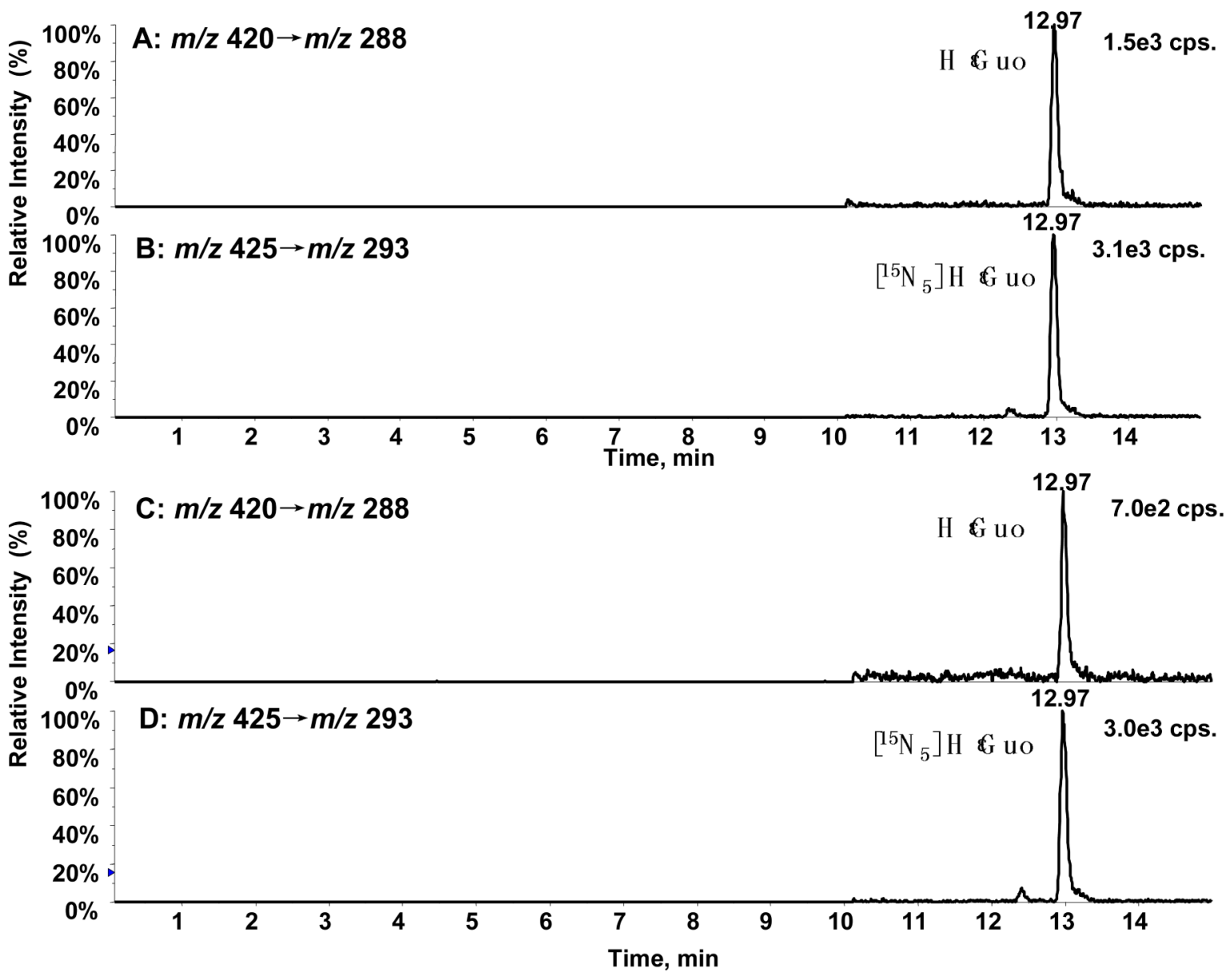

Figure 7.

LC-ESI/MRM/MS analysis of HeGuo and its corresponding $\left[{ }^{15} \mathrm{~N}_{5}\right]$ internal standard. (A) Authentic HeGuo standard (400 pg/mL). (B) Internal standard. (C) HeGuo (6.6 adducts per $10^{6}$ normal Guo bases) from RIES cell RNA. (D) Internal standard for RIES cell RNA. Ion chromatograms for HeGuo $(m / z, 420 \rightarrow m / z, 288)$, $\left[{ }^{15} \mathrm{~N}_{5}\right] \mathrm{H} \varepsilon \mathrm{Guo}(\mathrm{m} / z 425 \rightarrow m / z 293)$. 


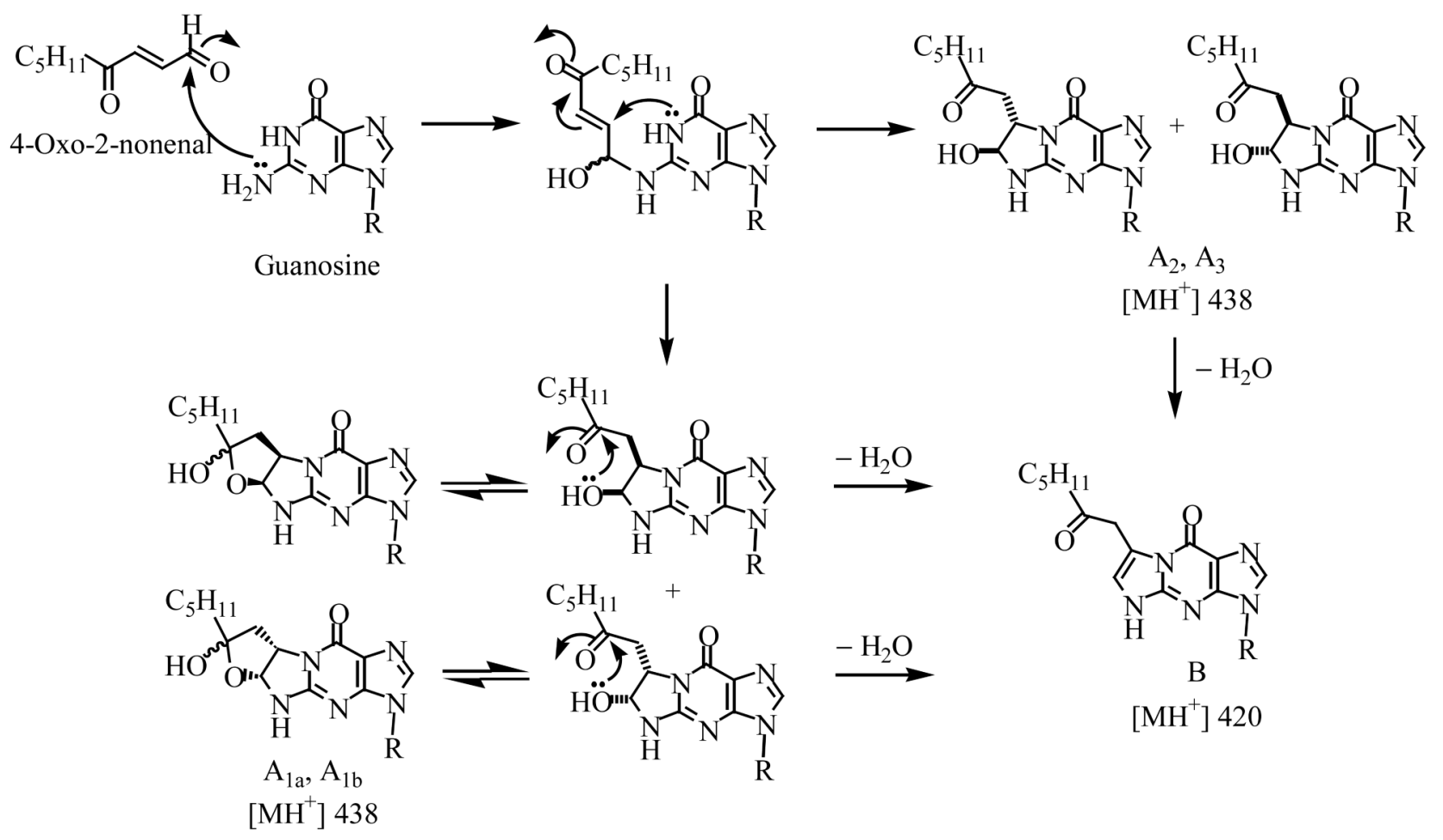

Scheme I.

Structures of adducts $\mathrm{A}_{1 \mathrm{a}}, \mathrm{AH}_{1 \mathrm{~b}} \mathrm{~A}_{2}, \mathrm{~A}_{3}$ and $\mathrm{B}$ and the mechanism for their formation. 
Table 1

${ }^{1} \mathrm{H}$ NMR assignments for adduct B. Spectra were obtained in DMSO- $d_{6}$.

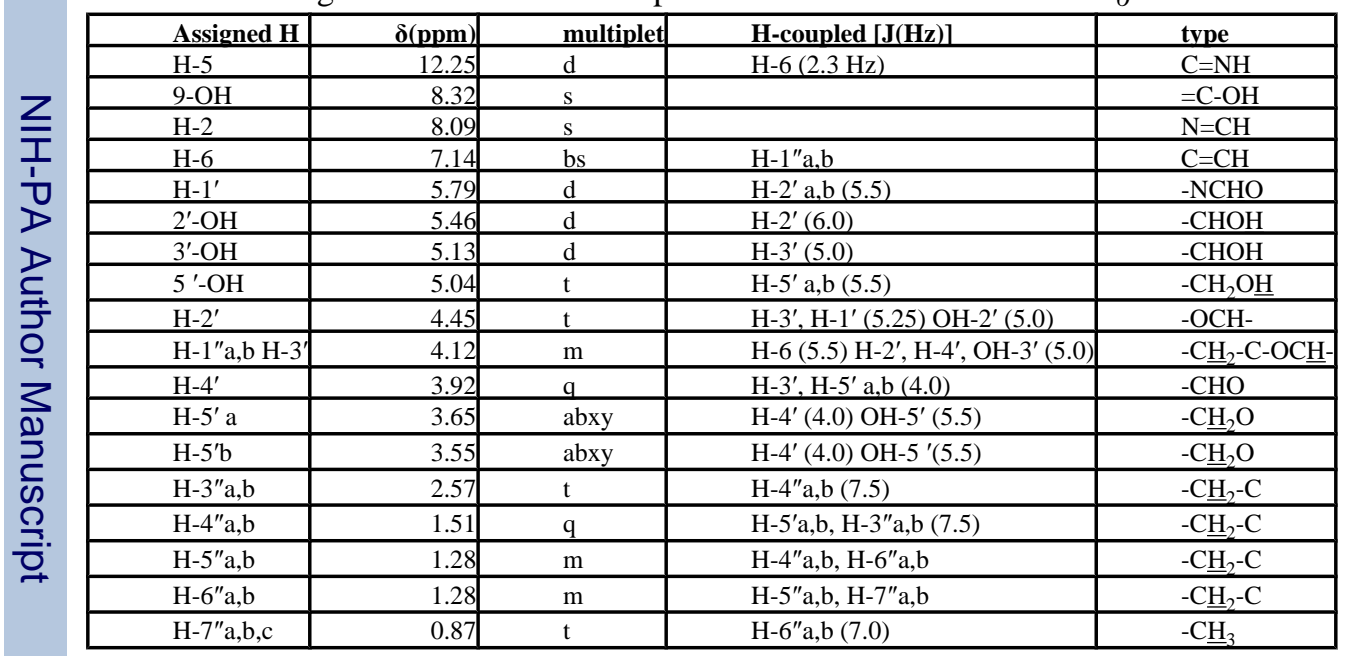

